\title{
Civil Society Organisations: Filling Up The Government Service Gap For National Development
}

\author{
Popoola Michael Akin, Omosebi Fredrick Adeola \\ Department Of History And International Studies \\ Babcock University, Ilisan-Remo, Ogun State \\ Adventist Development Relief Agency (Adra) \\ Seventh-Day Adventist Church Headquarters \\ Lagos, Nigeria
}

\begin{abstract}
Good governance is inextricably linked with development. That is why any government which is genuinely concerned about good governance makes the issue of development its central focus. However, the governments of many developing countries experience capacity deficit in the area of the requisite institutions, funds and capacity to foster comprehensive socio-economic development. This makes it imperative for the state to engage in collaborative relationship with civil society which can help to fill up the lacuna created by the lack of state institutional and technical capacity. The critical role of civil society in development is aptly appreciated by some donor institutions and western countries which channel their Official Development Assistance (ODA) to developing countries through civil society organisations for effective implementation.

This research therefore, undertakes an analysis of the way and manner which civil society organisations can complement the development efforts of the state. What makes this research crucial is the belief in some quarters that the state and civil society are often mutually conflicting and perpetually locked in zero sum game. However, this paper discovered that both the state and civil society are mutually reinforcing entities and that development is enhanced when there is collaborative efforts, rather than contestation between them.
\end{abstract}

Key words: Advocacy, Civil-Society, Complementary, Development, Partnership, State,

\section{Introduction}

The basic reason for the existence of government in modern day welfare state, is to improve the quality of public services and ensure the provision of life certainties to the citizens. The responsibility of the government also includes empowering the citizens to adequately and reasonably participate in decision making process, as well as creating the necessary environment that would simplify and facilitate communication between the citizens and the state administration on the basis of transparency and accountability. In other words, the citizens and the provision of their basic needs form the crux of the developmental drive of the government.

However, before any country can perform optimally and efficiently in achieving these objectives, it must possess the capacity to appropriately harness all its assets, such as capital, human and natural resources. It is only then the country can meet demands from its population as broadly as possible. Nonetheless, the government does not have the monopoly of management competence. The government of many states, especially in the Southern Hemisphere, experience capacity deficit in the area of the requisite institutions which can tap, attract, retain and use citizens' skill effectively in order to foster comprehensive socioeconomic development. One of the ways by which the state can make up for this apparent shortfall in institutional and technical capacity is by giving due recognition to civil society organisations(CSOs) and affording them the opportunity of participating in the developmental efforts of the state. (Imade 2007). 
The role of civil society organisations as partners in the development agenda of any nation cannot be overemphasized. This formed the fulcrum of the discussions at the conferences on aid effectiveness in Accra (Ghana) in 2008 and Busan (South Korea) in 2011. The critical role which CSOs could play in promoting development as well as advancing democratic principles spurred the countries which were represented at the conferences to commit themselves to the creation of a conducive environment that would provide the necessary support for civil CSOs to thrive. The enabling environment would no doubt encourage them to perform their required roles as autonomous actors which are critical to development process. As a matter of fact, the contemporary theories of liberal democracy have established the mutual interdependence which exist between civil society and the modern democratic state as a necessary opportunity for development.

The impact of civil society organizations on a nation's development however, depends on the relationship which exist between them and the government. In some developing countries, the relationship between the government and civil society is always adversarial, antagonistic, laden with suspicion, in which there is no common starting point for both parties (Sievers 2009) Such states view civil society as rivals in service delivery, competitors for funds, unnecessary scrutinizers of government activities or outright challenger of government authority which should not be tolerated or accepted. Civil society organizations which operate in such emasculated situation often function as rubble rousers and play oppositional role instead of complementary role. This kind of relationship retards development.

But in some other countries, the relationship between the state and civil society involves a constructive and genuine partnership which enable both parties to collaborate to tackle some mutually agreed challenges. Civil society organisations in such countries, act as major agents of development and a complement to the state. They respond to the failure of the public sector by initiating and implementing their own projects, thereby supporting the government efforts towards development.

The objective of this research therefore is to engage in an exposition of the way and manner civil society organisations enhance the socio-economic and political development of a nation as well as how the two pillars of democracy (the state and civil society) could act as mutually reinforcing entities. The study is very essential at this point in time when the belief is rife in some quarters that the state and civil society are mutually conflicting and perpetually competing entities, locked in zero sum game. (Hadenius, 1996).

\section{Literature Review}

The emerging universal consensus on the interlinks between civil society and sustainable development cannot be termed a misplaced priority. Political scholars as well as public policy analysts opine that civil society organizations can play enormous roles to complement the developmental efforts of the government as they struggle to advance good governance, especially in an emerging state. Hence, partnership between the state and civil society is now being regarded as a new vista of opportunities to initiate and implement effective development policies in any country.

Macedo (2011) argues that public policies, including developmental agenda, are more effective when solid relationship exists between the state and civil society. According to him, an established and sustained partnership between civil society and the state will undoubtedly encourage more political participation by a variety of different actors in the state and this in turn would impact on development.

Essia and Yearoo (2009) observe that partnership or collaboration between the state and civil society is a requisite factor for civil society to play its required role in complementing the developmental efforts of the state. In his own words, Imade (2007), states that the best and perhaps the only chance to bring about a more sustainable peace, economic development and stable government is to give civil society a greater role in governance. Aderounmu (2010) too emphasizes the fact that civil society cultivates the political conditions within which development thrives. He states further that "for sustainable development initiatives to take root, there must be a stable, democratic and accountable government and the pivotal role of civil society in achieving this cannot be underestimated"

The views expressed above reiterates the fact that for a state to possess a vibrant democratic institution, initiate and implement sustainable developmental programmes, there must be a critical and articulate mass of citizens who are well educated about their rights, concern themselves with the long term goals of the community and relate freely to maintain free exchange of ideas. Since it is often said that power belongs to 
the people, the mass of citizens, referred to as civil society must be given the necessary conducive environment to engage in constant interactions with the government.

While harping on the essence of state and civil society relationship, the incumbent German Chancellor, Angela Merkel, opines that civil society can help to stabilise democracy and advance development to the extent that civil society is given the latitude and conducive environment to Operate (De Neve, 2012). Merkel therefore, advocates that the state must be the gardener and not the fence to civil society. This agrees with the position of Chukwuma (2011) who states that the central role which civil society has assumed in the development of modern society makes it imperative for any state which is desirous of harnessing the potentials of its citizens for national development to embrace it.

The foregoing makes it clear that civil society has been widely recognized as an essential 'third' sector whose vitality can have a positive influence on the state (which is referred to as first sector) and the market (which is known as second sector). Civil society is increasingly growing from being implementing partner to sharing more responsibility with the state in development policies. In other words, the effectiveness of the state efforts to achieve development goals rest basically on the quality of its governance and the extents to which the government interacts with and co-opt civil society in achieving this end

\section{Civil Society and Donor Agencies}

.Realising the importance of the advocacy and direct roles which civil society plays in promoting developmental agenda, some international donor agencies and governmental organisations consider it as a critical partner and place high premium on it as ally by investing a lot of money to strengthen it. The donors consider civil society's technical expertise, knowledge of rural communities and its advocacy for human and civil rights as useful tools of spreading development (Katrisiku, 2010). Therefore, some of the donors (like the World Bank, United Nations Development Programme (UNDP), the British Department for International Development (DFID) and the United States Agency for International Development) channel their funds for Official Development Assistance (ODA) through civil society organizations (USAID 2005).

For instance, the Ghanaian government was able to secure the World Bank loan to address HIV/AIDS pandemics in 2005 because of the commitment made by the government that 70 per cent of the funds would be given as grants to civil society organizations to implement HIV/AIDS programme. As a result of this development, new civil society organizations sprang up to join the already existing ones in Ghana and they took message about HIV/AIDS to all the nooks and crannies of the country. Consequently, a drastic reduction in the prevalence of the pandemic was recorded from 34 per cent in 2002 to 1.37 per cent in 2016.

Moreover, the government of Canada considers civil society as an important partner in engendering transformative change and promoting community-government engagement. This is why the country supports and encourages the creation of enabling environment for civil society in the developing countries to function effectively and independently. In the same vein, the United States Agency for International Development (USAID) posits that its central component of promoting development and governance agenda in the southern hemisphere would rest on its support for civil society.

The Former American President, Barrack Obama, justified his choice of Ghana as the first country he visited in sub-Saharan Africa as he said, 'My choice of destination was intended partly to highlight the critical role that sound governance and civil society play in promoting lasting development (Bruce, 2009).

These instances reinforce the growing realisation that an independent centre of social and economic power is sine qua non to socio-economic development of a nation. This is exemplified in the experience of The United States of America where more human services funded by the government at the national level are delivered through civil society groups than government agencies. This made an observer to remark that "The American welfare state is not run by the state, but by a host of non-governmental third parties'.

\section{The Involvement of Civil Society in socio-political and economic Development}

Civil society organizations make their impact in development through the provision of relief and basic services, building the capacity of the government agencies, and advocating on behalf of the masses. Their influence on development is not exhaustive because it increases with time.

Below are the analysis of some of the ways through which civil society organisations make positive impact on development. 


\section{Engagement in Poverty Alleviation}

Undoubtedly, the goal of development and the process of nation building cannot be achieved in any state without ameliorating the living conditions of the downtrodden people. But many states lack the necessary facilities or economic capabilities to adequately perform this fundamental role. Hence, civil society organizations go beyond advocacy function by acting directly to bridge the gap created by the government neglect of the poverty stricken community (Chandan, 2014). This is done through the provision of some basic services like improving the local business investment climate, encouraging new enterprises and responding to humanitarian emergencies by delivery of social services directly to the poor people.

For instance, Bina Swadaya; a prominent civil society organization in Indonesia has developed various business oriented activities tagged 'Fund Rising Activities' which are targeted at poverty alleviation. The organization maintains about 23 representative offices in various regions of the country through which it works with the local people to address issues of poverty (Suharko, 2007). It also develops local institutions such as 'Self Help Groups' (SHGs) which is assisted to developed microfinance and micro business. Other activities of this civil society organisation include building training centers, developing rural banks and selling agricultural products and providing professional advice to the down- trodden. The efforts of Bina Swadya and several other CSOs in Indonesia have significantly reduced poverty level from about 25 per cent in 1999 to 10.86 per cent in 2016. A World Bank report in 2016 showed that out of a population of 252 million, only about 28 million live below the poverty line in Indonesia (World Bank, 2016)

Furthermore, in Kenya, Zimbabwe and Ghana, CSOs now provide 40 per cent of all health and education services. In Bangladesh too, there are about 22,000 development civil society organizations which provide education, health and credit facilities to between 25-30 per cent of the population (Shaw and Izumi, 2016). In rural Argentina, some civil society organisations work with local government to provide education and establish entrepreneurship training program for low income youth in the country. In the same vein, some civil society groups in Pakistan came together to build and operate schools either in collaboration with the government or independently of the government. These auxiliary functions of filling up the government service gap is one of the factors that make civil society and government collaboration imperative.

\section{Articulating the Views of the Vulnerable and Maginalised Population}

The vulnerable and the maginalised population such as the disabled, internally displaced people, children, women as well as indigenous religious and ethnic minorities are very important segments of the society and their needs and views need to be sought, harmonized and brought to the attention of the government. These groups of people, if ignored, are capable of constituting a very serious threat to the peace, stability and developmental efforts of the government. Such is the case in Nigeria where a perceived long time marginalization of some minority groups has led to restiveness of enormous magnitude which partly serve as hindrance to economic growth in the country.

Execution of developmental projects is the prerogative of every group or section of the nation. Nevertheless, it is very easy for the government to overlook the needs of certain groups due to some inexplicable reasons. The closeness of civil society organizations to the grassroots, coupled with their expertise knowledge in service delivery often place them at a vantage position to serve as the appropriate channel to articulate the needs of such classes of people, synchronize their loosely organized groups and associations, give expression to their values and beliefs, attune government programmes to their needs, disseminate democratic principles and ideas to them, mobilize them for political participation and inclusion in governance, encourage them to assume ownership of their development and embolden them to stand up for the defense of their human rights. This advocacy function forms one of the significant areas of intervention of civil society organisations as a critical partners in development. Several civil society organizations play this advocacy role in Ghana, particularly in the Northern part of the country which is the least developed.

\section{Bridging the Gap between the Citizens and the Government}

The success of any government project/programme requires that the target population understand and own the project. The objective behind the policy as well as the benefit the people will derived from it should be explained to them. This is very essential especially in the developing countries where the masses believe that there is a wide gap between them and the government- a belief that always make them to be skeptical about any government programme. Civil society is the only sector which can perform the dual functions of serving as a channel through which the objectives of government policies can be explained to the grassroots, and 
through which the people are empowered to participate in, or assume the ownership of the government development programme.

In Ghana, some civil society organizations like the Integrated Social Development Center (ISODEC) believe that one of the ways by which the gap between the government and the people could be bridged is through the involvement of the people in budget process. The involvement of people in the budget process would promote the people's ownership of the budget, engender transparency of public finance transactions and foster accountability of the public officials. This in turn would make the people to repose more confidence in the government and support any project to be executed with the budget. The effort of civil society organizations in this regard makes it possible for Ghanaian citizens to engage in budget process through two approaches; 'Ex-ante and Ex-post'. The Ex ante approach enables the stakeholders to present their views to the relevant authority to be included in the budget, while Ex-post approach enables the citizens to carry out the assessment of the degree to which the budget succeeded in achieving the objectives of the government and the yearnings of the society in general (ISODEC, 2011). The effort of civil society in this regard has succeeded in creating an informed and educated citizenry in Ghana which is always ready to identify with government programmes, and or prepared to work for their success.

\section{Involvement in Environmental issues}

Environmental agenda is no doubt one of the issues that occupy the front burner of national and international discourses in recent times. This began in 1972 when the representatives of about 112 countries gathered in Stockholm for the United Nations Conference on Human Environment. Since then, environmental issues have remained central in the development plans of governments at local, national and international levels. Civil society organizations play enormous complementary roles in contributing to a sustainable environmental management process. These roles include; shaping and influencing government policies on environmental issues, advocacy for community involvement at every level of environmental sustainable development, sensitization of individuals to issues of environmental concerns and shaping their attitudes towards them (Rosenbaum, 2002). Others include, capacity building and the empowerment of the local population, research, networking, partnership, expertise analysis, monitoring of compliance with environmental agreement and evaluation of government environmental policies. The critical roles which civil society organizations play in environmental governance encouraged the United Nations Organization to recognise them as partners, particularly in environmental negotiations. As a matter of fact, Agenda 21 of the U.N Conference on Environment and Development states inter alia

The United Nations system, including international finance and development agencies and all intergovernmental organizations and forums should in consultation with non-governmental organization take measures to enhance existing, or where they do not exist, establish mechanism and procedures within each agency to draw on the expertise and views of Non-Governmental Organization in policy and programme design implementation and evaluation (UN,1994, Chapter 27, adapted from Rosenbaum, 2002).

This gave rise to proliferation of environmental oriented civil society organizations around the globe. While some of them complement the efforts of their respective governments by engaging in advocacy and direct execution of projects on conservation of the environment in the affected communities, some merely exist to collect the donors fund. In India, civil society organisations such as Narmada Bachao Andalon, Kalpavriksh and the Center for Environmental Education exist to conduct widespread education and training programmes on environmental protection to the youth in their schools and the older folks in their various localities. (Rosenbaum, 2002)

Another example of state and civil society collaboration on environmental issue is found in SriLanca, where the government co-opted the representatives of some civil society organizations into the National Environmental Council which reports to the Prime Minister on the environmental ramifications of all major development projects in the country. 


\section{Provision of Relief Assistance during Disaster}

When disaster strikes, the government does not reserve the right of being the sole author of wisdom on how to proffer solution to it. Civil society organizations often respond to disaster by engaging in risk assessment, mobilizing funds for relief materials and rehabilitation as well as distributing relief materials. This is a very important function of civil society especially in areas where the government does not possess the capacity to cope with the magnitude of the disaster. For instance, the humongous humanitarian crisis created by Boko Haram insurgency in the Northeastern region of Nigeria is beyond what the government alone could tackle. The Adventist Development and Relief Agency (ADRA) is one of the numerous civil society organisations/ non-governmental organisations that damn the volatile security challenges of the region to reach the people that were displaced from their homes by the insurgency. ADRA's activities in the region include; engaging in the distribution of disaster relief materials, provision of shelter, potable water, sanitation and access to education to the Internally Displaced People (IDPs), empowering and changing the lives of victims of insurgency, providing psychological support to them and giving the affected communities access to sustainable development. In the last few years, ADRA and other humanitarian CSOs operating in the Northeastern part of the country have engaged in disaster risk reduction and provision of livelihood support projects which have impacted positively on the lives of over one million IDPs in that part of Nigeria (ADRA,2017).

\section{Enhancing the Capacity of State Officials}

Civil society organisations enhance state competence through building the skills and capacity of state officials and institutions to make them work more effectively and efficiently. The African Parliamentary Centre, (APC) is a civil society organisation based in Ghana which specializes in developing parliamentary capacity to exercise its oversight functions. The Parliamentary Centre regularly organises training programmes for Ghanaian parliamentarians in order to enhance their role as the defender of the public purse. The training which is sometimes extended to other parliamentarians in other West African countries, helps the law makers to understand the nitty-gritty of financial scrutiny and how they could exercise effective oversight of revenue management (OSJI,2011)

The Centre for Democratic Development (CDD) which is based in Ghana as well, also engages in building the capacities of some Parliamentary Committees such as the Judicial Committee, Constitutional and Legal Affairs Committee, and Government Assurance Committee, to enable them make laws in conformity with the constitution of the country. In addition, CDD works with the country's Electoral Commission to review electoral process. This enhance the performance of the Electoral Commission and also strengthen the confidence reposed in the electoral body by the citizens. In the same vein, the CLEEN Foundation and the Network of Police Reform in Nigeria (NOPRIN) provide training for the Nigerian Police in order to boost its performance in the task of crime detection. The two CSOs also provide trainings meant to acquaint the Nigerian police with the best practices around the world, especially on the issues of crime prevention and other acts that could help to revamp the battered image of the police force in the country.

\section{Public Policy}

Collaborative agreement between the state and civil society can also impact the government positively in the area of public policy formulation. Civil society can initiate and facilitate the passage of bills which could make the country a better society. For instance, the Institute of Economic Affairs (IEA) in Ghana initiated and facilitated the passage of some bills like, the whistle Blower Bill, Petroleum Revenue Management Bill, Local Content Bill, Presidential Transition Bill, Disability and mental Act, Domestic Violence Act, and several others. These have undoubtedly contributed to making Ghana a better society, generally referred to as the beacon of African democracy (OSJI, 2011).

\section{Impact on Democratisation}

It is no gainsay that democratization, democratic consolidation and good governance are concomitant to development. Many Third World countries which experienced military authoritarian regimes would not have embraced democracy without the active participation of civil society organisations in the democratization process. Their efforts in lending popular weight to transition programmes in countries like Nigeria and Ghana, coupled with other factors, culminated in the enthronement of democracy in such states. 
Similarly, it is common knowledge that democracy in many developing countries are still weak, vulnerable, inefficient and remain nascent, even many years after transition to civil rule. If the views of some political scholars are anything to go by, a nascent democracy cannot be strengthened or consolidated without the active involvement of civil society in the democratic space. This informed the position of Wong and Leung (2008) who posit that "to create and sustain democratic institutions, a society must possess a critical and vibrant mass of citizens who engage in constant social contact with each other for free exchange of ideas, who are well educated about their rights, and are concerned about the long term goal of the community as a whole".

Furthermore, civil society can work assiduously to eliminate the subtle dangers or threats which are capable of eroding the basic tenets of democracy. Artwood (2006) states that democracy can experience progressive diminution of the existing spaces for the exercise of civilian power. For instance, state violence as well as state weakness may subvert the rule of law, the rise of hegemonic parties may suffocate electoral competition, the decay of electoral institutions may affect the honesty of vote counting and the incumbents may use their privileged access to state resources and the mass media to violate the minimum standard of electoral fairness and equal opportunity. All these could facilitate what some scholars refer to as 'slow death' for democracy. But the activities of pro-democracy CSOs such as constant monitoring of state activities, demanding for accountability and transparency from the government, holding the government officials responsible for their actions, and struggling for the guarantee of the rule of law and fundamental human rights can go a long way to prevent the slow death of democracy and in turn put a state on the path of democratic consolidation.

\section{.Factors Responsible for Tension between civil Society and the State}

In spite of the propensity for collaboration, between the state and civil society and the enormous prospect for development which could arise from it, the relationship between civil society and the government, especially in most of the Third World countries, is characterized by mistrust, tension and suspicion. Some of the reasons responsible for this are discussed below.

Sometimes, the government is suspicious of or feel uncomfortable with the ideas coming from another quarters outside of the government. Whenever this happens, what would have been a simple consultation between civil society and the government would result into confrontation. Development would unarguably be at the receiving end of this lack of mutual acceptance (Rajesh, 1991)

Furthermore, some civil society organisations assume the role of providing competing alternatives to the government rather than see themselves as agents of complementary contributions. Consequently, they present government officials as being arbitrary, irresponsible and irresponsive to the needs of the masses. On the other hand, the government see civil society organizations as being too aggressive and self aggrandizing, engaging in distortion of facts so as to increase their criticism of the government. The government sometimes claim that civil society organisations threaten the national security in the course of pursuing their agitation and accuse them of being tools in the hands of the opposition parties to destabilize the government in power. This lack of mutual respect and acceptance cannot give room for any genuine collaboration since no government would be at ease with any group that may tend to undermine the authority of the state (Rajesh, 1991).

Furthermore, some civil society groups are not comfortable with collaborative relationship with the government because of the fear that such collaboration may be very risky and inimical to their existence. They consider the fact that partnership with the state will make them financially dependent on the state, corrupt them, reduce their autonomy, make them complacent and eventually debar them from making profound impact on behalf of the masses. Clark (2004) must have alluded to this view as he states that "too much of familiarity between civil society and the government would make civil society accept any information given by the government hook, line and sinker without any critical analysis...This undoubtedly will defeat the raison d'etre of the existence of civil society". This fact may be the reason why some civil society organizations are cautious of their relations with the government. Even when situation makes it compulsory for them to relate with the government, they do it with suspicion. For instance, the civil society organizations that assisted the Hong Kong government during the outbreak of the Severe Acute Respiratory Syndrome (SARS) rendered their assistance with serious care and mistrust. 
Lastly, lack of common objective and similar priority may prevent a robust collaborative agreement. For example, a civil society organization advocating the creation of an environment free from greenhouse gasses may find itself at variance with the government if such an issue is not in the agenda priority of the government.

\section{.Conclusion}

In conclusion, civil society organizations have been identified as an indispensable agent of complementary contributions to the developmental efforts of any government. Its resourcefulness and innovativeness in working with local communities to identify and resolve problems associated with development in a sustainable and cost effective manner and in a way compatible with community values and norms makes partnership between them and the government imperative.

Judging from the findings of this study therefore, the researcher agrees with the position of the former UN Secretary General, Kofi Annan, that partnership between the state and civil society organisations are no longer an option but a necessary requirement for the achievement of even development.(WASCI, 2007). This assertion has been demonstrated in many countries where civil society organisations have complimented, informed, influenced and challenged the government on behalf of the masses. However, for this working relationship and partnership to be sustained, civil society organizations need a conducive environment to thrive and function maximally. The enabling environment includes a supportive legal environment which would guarantee the essential legal framework for civil society activities, and as well promote the rule of law and respect for human rights. It also includes a political atmosphere which will encourage freedom of association, expression and peaceful assembly. Therefore, this research would conclude by saying that contrary to the belief in some quarters that the relationship between the state and civil society is always conflictual, it is very possible for civil society organizations and the government to harmonize their differences and collaborate together for the purpose of development. This is a task that all responsible governments should take very serious, knowing full well that it is only a strengthened civil society that can efficiently work in partnership with the government and keep the government on track of the issues of public developmental concerns which undoubtedly, constitute an integral part of the reason for the existence of the government.

\section{References}

[1] Aderounmu, J. A (2010), "Civil Society and Democratic Consolidation in Nigeria" in V.Egwemi, (ed) A Decade of Democracy in Nigeria 1999-2009, Issues, Challenges and Prospect of Consolidation. Markudi: Aboki Publishers.

[2] ADRA (2017) Statement of operational Intent: Humanitarian Crisis in the Northeast. Situation Report.

[3] Atwood, B. (2006), Good governance and Civil Society, Democratising Demcracy in Nigeria http://portal,uam.es/portal/page/portal/UAMORGANISATIVO/Departamentos/c enciap (Accessed on 13/04/2017)

[4] Bruce, G. (2009), Quoting President Barack Obama speech in "civil Society, Democracy and Election" htm Accessed on (12/06/2017)

[5] Chandan, K. D. (2014) The Role of Civil Society in Poverty Alleviation and Social Inclusion: Challenges and Expectation. Asian Journal of Research in Social Sciences and Humanities, Vol.4,No 11, Nov.

[6] Chukwuma, I. (2011), Government and Civil Society Partnership in Nigeria: Problem andProspect, www.cleen.org/government-civilsocietypatnership.pdf (Accessed 13/04/2017)

[7] Clark, J. (2004), The Relationship Between the State and the Voluntary Sector. www.gdre.org/ngo/ncafe-ks.html (Accessed 14/06/2017)

[8] De Neve, D. (2012), Civil Society and Governance: Pluralizing the State, Friedrich-Ebert Stiflung

[9] Essia, U. and Yearoo, A. (2009), "Strengthening Civil Society Organisations/GovernmentPartnership in Nigeria" in International NGO Journal, Vol.4 (9)

[10] Hadenius, A. and Uggla, F. (1996), Making Civil Society Work, Promoting Democratic Development: What can States and Donors Do? World Development, Vol.24, no.10 
Nigeria"http://portal,uam.es/portal/page/portal/UAMORGANISATIVO/Departamentos/c enciap (Accessed 13/05/2017)

[12] Integrated Social Development Centre (ISODEC) (2011), Homepage http://www.isodec.org.gh. (Accessed 16/04/ 2017)

[13] Katsriku, B. (2010), "The Paradox of Public Service-Civil Society Collaboration in Ghana", A Conference Paper delivered at CAPAM Africa Regional Conference, held from $17^{\text {th }}-19^{\text {th }}$ May.

[14] Macedo, J. P. (2011), Civil Society and the State: A Partnership for the Revitalisation of Democracy and Coherence Multilevel Global Governance, www.bertelsmann stiftung de (Accessed on $23 / 04 / 2017$ )

[15] Open Society Justice Initiative (OSJI) (2011), Press Release, May 31.

[16] Rajesh, T. (1991) The Relationship Between NGO and Government: A Source of Life or a Kiss of Death? New Delhi, Society for Participatory Research in Asia.

[17] Rosenbaum, A., (2002). Cooperative Delivery of Public Services: Reflections on the Dynamics of Public Sector-Private Sector-Civil Society Collaboration on Government Service Delivery. A paper delivered at the $4^{\text {th }}$ Global Forum on Reinventing Government Capacity Marakkesh, Morocco. Dec.10-11.

[18] Shaw, R. and Izumi T. (2016) Civil Society Organisation and Disaster Risk Reduction: The Asian Dilema. Springer International Publishing.

[19] Sievers, B. (2009) What is Civil Society? G/A Readers, Vol. 20, No. 1, Spring.

[20] Suharko, J. The Role of NGOs in Rural Poverty Reduction: The Case of Indonesia and India, , October, 2007, Graduate school of Int'l Development, Nagoya University, Nagoya, Japan.

[21] United States International Agency for Aid and Development (USAID) (2010), Annual Report.

[22] USAID (2005), "Increased Development of a Politically Active Civil Society". www.usaid.gov/our_work/democracy_and_governance//ethical_areas/civil_soceity/ (Accessed 22/06/2017)

[23] Wang, H. and Leung, T. F., (2008) Collaborative Vs Adversarial Relationship Between the State and Civil Society in Facing Public Disaster: A Case of Hong Kong in the SARS Crisis.

Asian Pacific Journal of Social Work and Development. Vol. 18, no 2

[24] West Africa Civil Society Institute (WASCI) (2008), Reflecting on Civil Society's Evolution In Ghana over the last 50 Years, Published by WACSI

[25] World Bank (2016) Annual Report. 